\title{
Predictors of favorable results in pulmonary tuberculosis treatment (Recife, Pernambuco, Brazil, 2001-2004)*
}

\author{
FATORES PREDITIVOS AO RESULTADO FAVORÁVEL DE TRATAMENTO DA \\ TUBERCULOSE PULMONAR (RECIFE-PERNAMBUCO, BRASIL, 2001-2004)
}

\author{
FACTORES PREDICTIVOS AL RESULTADO FAVORABLE DEL TRATAMIENTO DE LA \\ TUBERCULOSIS PULMONAR (RECIFE-PERNAMBUCO, BRASIL, 2001-2004)
}

\section{Cinthia Midori Sassaki ${ }^{1}$, Lucia Marina Scatena ${ }^{2}$, Roxana Isabel Cardozo Gonzales ${ }^{3}$, Antonio Ruffino- Netto $^{4}$, Paula Hino ${ }^{5}$, Tereza Cristina Scatena Villa ${ }^{6}$}

\begin{abstract}
Based on data available in the Information System for Notifiable Diseases, predictive factors of favorable results were identified in the treatment of pulmonary tuberculosis, diagnosed between 2001 and 2004 and living in Recife-PE, Brazil. Uni- and multivariate logistic regression methods were used. In multivariate analysis, the following factors remained: Age (years), 0 to 9 (OR=4.27; $\mathrm{p}=0.001)$ and 10 to $19(\mathrm{OR}=1.78 ; \mathrm{p}=0.011)$, greater chance of cure than over 60; Education (years), 8 to 11 (OR=1.52; $\mathrm{p}=0.049$ ), greater chance of cure than no education; Type of entry, new cases (OR=3.31; $p<0.001)$ and relapse $(\mathrm{OR}=3.32 ; \mathrm{p}<0.001)$, greater chances of cure than restart after abandonment; Time (months) 2, 5- 6 (OR=9.15; $\mathrm{p}<0.001) ; 6-9(\mathrm{OR}=27.28 ; \mathrm{p}<0.001)$ and More than 9 (OR=24.78; $p<0.001)$, greater chances of cure than less than 5 ; Health Unit District, $D S$ I (OR=1.60; $\mathrm{p}=0.018)$ and $D S I V$ $(O R=2.87 ; p<0.001)$, greater chances of cure than $D S$ VI.
\end{abstract}

\begin{abstract}
RESUMO
Partindo de dados disponíveis no Sistema de Informação de Agravos de Notificação, identificaram-se e analisaram-se fatores preditivos ao resultado favorável de tratamento dos casos de tuberculose pulmonar, diagnosticados no período de 2001-2004, residentes em Recife-PE. Utilizaram-se métodos estatísticos uni e multivariado de regressão logística. No multivariado permaneceram: Idade (anos), 0 a 9 (OR=4,27; $\mathrm{p}=0,001$ ) e 10 a $19(\mathrm{OR}=1,78 ; \mathrm{p}=0,011)$, maior chance de cura que mais de 60; Escolaridade (anos), 8 a 11 (OR=1,52; $\mathrm{p}=0,049)$, maior chance de cura que nenhuma escolaridade; Tipo de entrada, casos novos ( $\mathrm{OR}=3,31 ; \mathrm{p}<0,001)$ e recidiva $(\mathrm{OR}=3,32 ; \mathrm{p}<0,001)$, maiores chances de cura que reingresso pós-abandono; Tempo (meses) 2, $5-16$ (OR=9,15; $\mathrm{p}<0,001) ; 6-9(\mathrm{OR}=27,28 ; \mathrm{p}<0,001)$ e Mais de $9(\mathrm{OR}=24,78 ; \mathrm{p}<0,001)$, maiores chances de cura que menor que 5 ; Distrito da Unidade de Saúde, $D S$ I (OR=1,60; $\mathrm{p}=0,018)$ e $D S I V(\mathrm{OR}=2,87 ; \mathrm{p}<0,001)$, maiores chances de cura que $D S$ VI.
\end{abstract}

\section{DESCRITORES}

Tuberculose.

Resultado de tratamento.

Sistemas de Informação.

Vigilância epidemiológica.

Eqüidade.

\begin{abstract}
RESUMEN
Considerando datos disponibles en el Sistema de Información de Enfermedades de Notificación, fueron identificados y analizados factores predictivos al resultado favorable del tratamiento de los casos de tuberculosis pulmonar, diagnosticados entre 20012004, correspondientes a residentes en Recife-PE (Brasil). Fueron utilizados métodos estadísticos univariado y multivariado de regresión logística. En el multivariado se consideraron: edad (años), 0 a 9 (OR= 4,27; $\mathrm{p}=0,001)$ y 10 a $19(\mathrm{OR}=1,78 ; \mathrm{p}=0,011)$, mayor chance de cura que más de 60; escolaridad (años), 8 a 11 (OR=1,52; $\mathrm{p}=0,049$ ), mayor chance de cura que ninguna escolaridad; tipo de entrada, casos nuevos ( $\mathrm{OR}=3,31$; $\mathrm{p}<0,001)$ y recidiva $(\mathrm{OR}=3,32 ; \mathrm{p}<0,001)$, mayores chances de cura que reingreso tras abandono; tiempo (meses) $2,5-16$ (OR= 9,15; $p<0,001) ; 6-9$ (OR=27,28; $p<0,001)$ y Más de 9 (OR=24,78; $p<0,001)$, mayores chances de cura que menor que 5 ; distrito de la Unidad de Salud, $D S$ I (OR=1,60; $\mathrm{p}=0,018)$ y $D S I V(O R=2,87 ; p<0,001)$, mayores chances de cura que $D S$ VI.
\end{abstract}

\section{DESCRIPTORES \\ Tuberculosis. \\ Resultado de tratamiento. Sistemas de Información. Vigilancia epidemiológica. Equidad.} * Extraído da tese "Fatores preditivos para o resultado de tratamento da tuberculose pulmonar no município de Recife-PE: uma contribuição para as ações de
vigilância epidemiológica, Programa de Pós-Graduação Enfermagem em Saúde Pública da Escola de Enfermagem de Ribeirão Preto da Universidade de São
Paulo, 2006". Enfermeira. Doutora em Enfermagem em Saúde Pública pela Escola de Enfermagem de Ribeirão Preto da Universidade de São Paulo. Profes-
sora Visitante do Colegiado de Enfermagem do Departamento de Ciências da Vida da Universidade do Estado da Bahia. Ribeirão Preto, SP, Brasil.
midsas@eerp.usp.br ${ }^{2}$ Professora Doutora. Pesquisadora do Grupo de Estudos Epidemiológico-Operacionais da Rede Brasileira de Pesquisa em Tuberculose.
Ribeirão Preto, SP, Brasil. Imscatena@uol.com.br ${ }^{3}$ Professora Doutora da Universidade Federal do Mato Grosso. Cuiabá, MT, Brasil. enroisab@eerp.usp.br
${ }^{4}$ Professor Titular do Departamento de Medicina Social da Faculdade de Medicina de Ribeirão Preto da Universidade de São Paulo. Ribeirão Preto, SP,
Brasil. aruffino@fmrp.usp.br ${ }^{5}$ Doutora em Enfermagem em Saúde Pública pela Escola de Enfermagem de Ribeirão Preto da Universidade de São Paulo. Pós
Doutoranda da Escola de Enfermagem da Universidade de São Paulo. Bolsista do CNPq. São Paulo, SP, Brasil. paulahino@yahoo.com.br ${ }^{6}$ Professora Titular
da Escola de Enfermagem de Ribeirão Preto da Universidade de São Paulo. Ribeirão Preto, SP, Brasil. tite@eerp.usp.br 


\section{INTRODUCTION}

Brazil comes in 16th place in the group of 22 countries with the highest notified tuberculosis (TB) burden in the world, with an estimated incidence rate of 60/100,000 inhabitants in 2004, for all forms of the disease. TB still kills at least 6,000 people per year in Brazil. Cure rate is $72.2 \%$ and default rate, $11.7 \%(1)$.

In the Brazilian Northeast, the state of Pernambuco is 2 nd in TB cases. There were 4,222 new cases in 2003, with an incidence rate of 51.7 cases per 100,000 inhabitants. In Pernambuco, 15 cities have received priority in the $\mathrm{Na}$ tional Tuberculosis Control Program(2). Recife is one of those cities and has high rates of incidence (111.95 per $100,000)$ and mortality (9.91 per 100,000) (SINAN/SMS, 2004; SIM/SMS, 2003). Default is around $15 \%$ and cure $60 \%(3)$.

Currently, the worst problems concerning TB occur when treatment is discontinued. This reduces the chances of cure and increases mortality and multiresistance indicators(4). Therefore, it is important to identify and analyze predictors associated with TB treatment with the goal of identifying the main obstacles to obtaining treatment success as well as to identify groups that demand specific care. An additional goal is to generate information that could help in the development of TB control policies, plans, organization, and evaluation of actions.

The purpose of this study is to identify and analyze predictors of treatment success for pulmonary TB cases diagnosed in the period from 2001 to 2004 in the city of Recife, Pernambuco, Brazil.

\section{METHOD}

This is a retrospective, analytical study which surveyed data from the National Case-registry database (SINAN) at the Epidemiologic Surveillance of Recife Health Department. Data analysis was performed using the Statistical Package for Social Sciences (SPSS, version 11.5).

Data selected from SINAN were: year of diagnosis, age, gender, education, district of residence, type of entry, supervised treatment, end-of-treatment date, district of the healthcare unit that followed the case, and HIV status. The data allowed for the definition of dependent and independent variables and their categories.

Binary dependent variables of TB treatment results were categorized into: favorable result and unfavorable result. Variables were grouped as follows: favorable result (1): cure; and unfavorable result (0): default, death, and Multiresistant TB. Independent variables were: year of diagnosis, age, gender, education, district of residence, type of entry, supervised treatment, Time 1 (date of diagnosis - start-of-treatment date), Time 2 (start-of-treatment date -end-of-treatment date), healthcare unit district, and HIV status.

Associations between favorable results and independent variables were identified through univariate analysis, and Wald's chi-square test was used to determine statistical significance. Univariate logistic regression model was used to establish odds ratio (OR), 95\% confidence intervals (CI-95\%) and Wald's chi-square test for each category.

Subsequently, multivariate analysis was done following the logistic regression model. Variables that presented descriptive significance levels $=0.20$ in the univariate analysis were included in the multivariate model. The backward-LR variable selection method was used, and variables were removed one by one if they presented a smaller degree of explanation for the dependent variable. This was according to significance of the logarithm of maximum likelihood ratio. Maximum error for null hypothesis to be rejected in all statistical tests was a significance level of $p<0.05$.

The study was approved by the Research Ethics Committee at Ribeirão Preto College of Nursing - University of Sao Paulo-USP, protocol 0584/2005.

\section{RESULTS}

Study population consisted of 4,750 cases. Table 1 shows the absolute frequency and percentage of cases with favorable and unfavorable results per category, as well as the univariate analysis results.

The variables gender, age, education, type of entry, supervised treatment, Time 1 , Time 2 , and healthcare unit district were associated with favorable TB treatment results in the univariate analysis $(p<0.05)$.

In the multivariate model, variables associated with $p<0.20$ were included in the univariate analysis (Table 1 ). The following variables were excluded: home district $(p=0.244)$; supervised treatment (because $65.54 \%$ of data within the category was ignored), and HIV (because $88.21 \%$ of data belong to the categories waiting for the result or not tested).

Predictors that remained in the final multivariate model were: age, education, type of entry, time 2 , and healthcare unit district (Table 2). 
Table 1 - Univariate analysis of the association between favorable result and independent variables of pulmonary TB cases diagnosed in the period of 2001 to 2004 - Recife, PE - Brazil

\begin{tabular}{|c|c|c|c|c|c|}
\hline \multirow[t]{2}{*}{ Variables } & Unfavorable result (0) & Favorable result (1) & \multirow[t]{2}{*}{ OR (IC 95\%) } & \multirow[t]{2}{*}{$\mathbf{P}$} & \multirow[t]{2}{*}{ Wald's Chi-square } \\
\hline & $\mathbf{N}(\%)$ & N (\%) & & & \\
\hline Year of Diagnosis & & & & 0.051 & 3.814 \\
\hline 2001 & 327 (32.77\%) & $671(67.23 \%)$ & 1.00 & & \\
\hline 2002 & $355(31.70 \%)$ & $765(68.30 \%)$ & $1.05(0.87-1.26)$ & 0.599 & 0.276 \\
\hline 2003 & $401(32.11 \%)$ & $848(67.89 \%)$ & $1.03(0.86-1.23)$ & 0.740 & 0.110 \\
\hline 2004 & $399(28.85 \%)$ & $984(71.15 \%)$ & $1.20(1.01-1.43)$ & 0.041 & 4.188 \\
\hline Gender & & & & 0.006 & 7.444 \\
\hline Male & $1,024(32.51 \%)$ & $2,126(67.49 \%)$ & 1.00 & & \\
\hline Female & $458(28.63 \%)$ & $1,142(71.38 \%)$ & $1.20(1.05-1.37)$ & 0.006 & 7.444 \\
\hline Age & & & & 0.000 & 82.100 \\
\hline 0 to 9 years & $20(15.87 \%)$ & $106(84.13 \%)$ & $4.29(2.59-7.10)$ & 0.000 & 31.97 \\
\hline 10 to 19 years & $66(18.97 \%)$ & $282(81.03 \%)$ & $3.46(2.53-4.73)$ & 0.000 & 60.17 \\
\hline 20 to 39 years & $611(29.35 \%)$ & $1,471(70.65 \%)$ & $1.95(1.61-2.35)$ & 0.000 & 48.37 \\
\hline 40 to 59 years & $522(32.50 \%)$ & $1,084(67.50 \%)$ & $1.68(1.38-2.04)$ & 0.000 & 27.73 \\
\hline 60 or more years & $263(44.73 \%)$ & $325(55.27 \%)$ & 1.00 & & \\
\hline Education & & & & 0.000 & 125.668 \\
\hline None & $113(30.96 \%)$ & $252(69.04 \%)$ & 1.00 & & \\
\hline 1 to 3 years & $100(28.99 \%)$ & $245(71.01 \%)$ & $1.10(0.80-1.51)$ & 0.566 & 0.329 \\
\hline 4 to 7 years & $300(23.73 \%)$ & $964(76.27 \%)$ & $1.44(1.11-1.86)$ & 0.005 & 7.76 \\
\hline 8 to 11 years & $122(20.54 \%)$ & $472(79.46 \%)$ & $1.73(1.29-2.34)$ & 0.000 & 13.12 \\
\hline 12 and more years & $29(16.11 \%)$ & $151(83.89 \%)$ & $2.33(1.48-3.68)$ & 0.000 & 13.33 \\
\hline Does not apply & $40(23.67 \%)$ & $129(76.33 \%)$ & $1.45(0.95-2.20)$ & 0.084 & 2.97 \\
\hline Ignored & $778(42.44 \%)$ & $1,055(57.56 \%)$ & $0.61(0.48-0.77)$ & 0.000 & 16.44 \\
\hline District & & & & 0.244 & 1.356 \\
\hline I & $148(30.64 \%)$ & $335(69.36 \%)$ & $1.23(0.98-1.56)$ & 0.076 & 3.15 \\
\hline II & $267(33.75 \%)$ & $524(66.25 \%)$ & $1.07(0.88-1.30)$ & 0.495 & 0.47 \\
\hline III & $268(30.35 \%)$ & $615(69.65 \%)$ & $1.25(1.03-1.52)$ & 0.023 & 5.19 \\
\hline IV & $149(22.71 \%)$ & $507(77.29 \%)$ & $1.86(1.48-2.32)$ & 0.000 & 29.30 \\
\hline $\mathrm{V}$ & $297(31.70 \%)$ & $640(68.30 \%)$ & $1.18(0.97-1.42)$ & 0.093 & 2.81 \\
\hline VI & $353(35.30 \%)$ & $647(64.70 \%)$ & 1.00 & & \\
\hline Type of Entry & & & & 0.000 & 227.614 \\
\hline New case & $898(25.45 \%)$ & $2,631(74.55 \%)$ & $3.48(2.81-4.30)$ & 0.000 & 130.39 \\
\hline Recurrence & $111(29.13 \%)$ & $270(70.87 \%)$ & $2.89(2.14-3.89)$ & 0.000 & 48.58 \\
\hline Does not know & $240(69.77 \%)$ & $104(30.23 \%)$ & $0.51(0.38-0.70)$ & 0.000 & 18.29 \\
\hline Forwarded & $23(21.10 \%)$ & $86(78.90 \%)$ & $4.44(2.69-7.33)$ & 0.000 & 33.88 \\
\hline Retreatment after default & $210(54.26 \%)$ & $177(45.74 \%)$ & 1.00 & & \\
\hline HIV & & & & 0.109 & 2.564 \\
\hline Positive & $110(51.64 \%)$ & $103(48.36 \%)$ & 1.00 & & \\
\hline Negative & $75(21.61 \%)$ & $272(78.39 \%)$ & $3.87(2.67-5.61)$ & 0.000 & 51.20 \\
\hline Waiting for result & $94(25.07 \%)$ & $281(74.93 \%)$ & $3.19(2.24-4.56)$ & 0.000 & 40.84 \\
\hline Not tested & $1,203(31.53 \%)$ & $2,612(68.47 \%)$ & $2.32(1.76-3.06)$ & 0.000 & 35.34 \\
\hline Supervised Treatment & & & & 0.000 & 25.641 \\
\hline Yes & $201(19.80 \%)$ & $814(80.20 \%)$ & $2.29(1.83-2.87)$ & 0.000 & 52.42 \\
\hline No & $225(36.17 \%)$ & $397(63.83 \%)$ & 1.00 & & \\
\hline Ignored & $1,056(33.92 \%)$ & $2,057(66.08 \%)$ & $1.10(0.92-1.32)$ & 0.280 & 1.17 \\
\hline Time 1 & & & & 0.000 & 389.190 \\
\hline 0 days & $920(26.29 \%)$ & $2,580(73.71 \%)$ & $2.03(1.36-3.04)$ & 0.001 & 11.80 \\
\hline 1 to 7 days & $115(24.78 \%)$ & $349(75.22 \%)$ & $2.20(1.40-3.44)$ & 0.001 & 11.78 \\
\hline 8 to 15 days & $19(13.87 \%)$ & $118(86.13 \%)$ & $4.50(2.40-8.41)$ & 0.000 & 22.13 \\
\hline 16 to 30 days & $19(19.39 \%)$ & $79(80.61 \%)$ & $3.01(1.59-5.70)$ & 0.001 & 11.42 \\
\hline Over 30 days & $42(42 \%)$ & $58(58 \%)$ & 1.00 & & \\
\hline Inconsistent & $367(81.37 \%)$ & $84(18.63 \%)$ & $0.17(0.10-0.26)$ & 0.000 & 58.02 \\
\hline
\end{tabular}




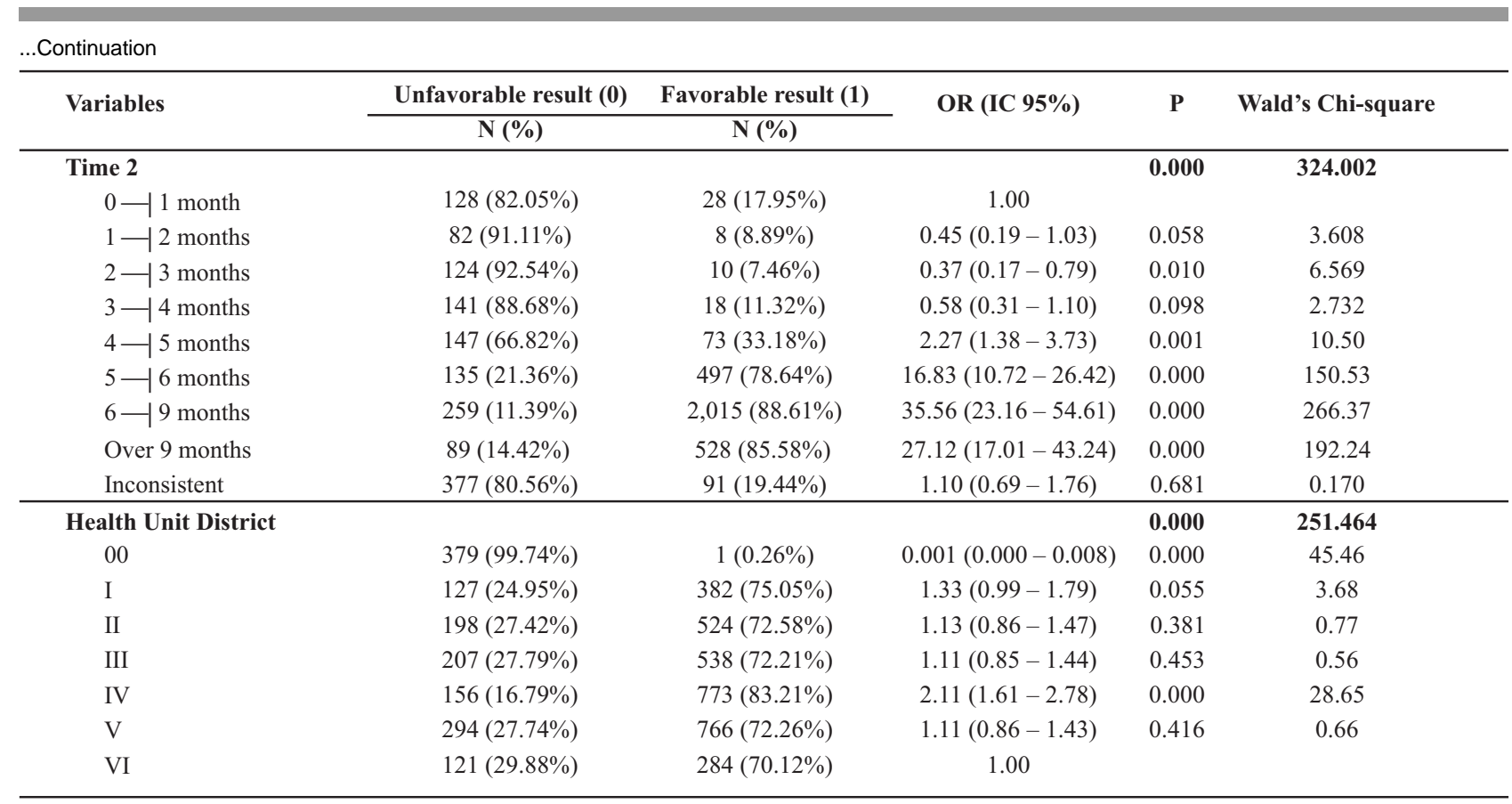

Reference level - Categories considered to have lower chance of obtaining a favorable result: year2001; males; Age 60 or more years; No Education; District VI: type of entry: retreatment after default; HIV Positive; no ST; Time 1 - over 30 days; Time 2 - $0-11$ month; Unit belonging to District VI.

Table 2 - Multivariate analysis of the association between favorable result and independent variables of pulmonary TB cases diagnosed in the period of 2001 to 2004 - Recife, PE - Brazil

\begin{tabular}{|c|c|c|c|}
\hline Variables & OR (IC 95\%) & $\mathbf{p}$ & Wald's Chi-square \\
\hline \multicolumn{4}{|l|}{ Age } \\
\hline 0 to 9 years & $4.27(1.76-10.37)$ & 0.001 & 10.268 \\
\hline 10 to 19 years & $1.78(1.14-2.78)$ & 0.011 & 6.474 \\
\hline 20 to 39 years & $1.14(0.84-1.55)$ & 0.386 & 0.752 \\
\hline 40 to 59 years & $1.11(0.81-1.51)$ & 0.517 & 0.421 \\
\hline 60 or more years & 1.00 & 0.003 & 16.092 \\
\hline \multicolumn{4}{|l|}{ Education } \\
\hline None & 1.00 & 0.000 & 28.218 \\
\hline 1 to 3 years & $1.06(0.68-1.66)$ & 0.799 & 0.065 \\
\hline 4 to 7 years & $0.99(0.69-1.41)$ & 0.960 & 0.003 \\
\hline 8 to 11 years & $1.52(1.00-2.29)$ & 0.049 & 3.883 \\
\hline 12 and more years & $1.55(0.85-2.85)$ & 0.154 & 2.030 \\
\hline Does not apply & $0.45(0.23-0.88)$ & 0.019 & 5.471 \\
\hline Ignored & $0.75(0.52-1.07)$ & 0.112 & 2.531 \\
\hline \multicolumn{4}{|l|}{ Type of Entry } \\
\hline New case & $3.31(2.50-4.38)$ & 0.000 & 69.566 \\
\hline Recurrence & $3.32(2.22-4.97)$ & 0.000 & 34.039 \\
\hline Does not know & $3.05(1.75-5.31)$ & 0.000 & 15.500 \\
\hline Forwarded & $5.58(2.88-10.83)$ & 0.000 & 25.919 \\
\hline Retreatment after default & 1.00 & 0.000 & 75.459 \\
\hline \multicolumn{4}{|l|}{ Time 2} \\
\hline $0-1$ month & 1.00 & 0.000 & 858.182 \\
\hline $1-2$ months & $0.26(0.11-0.62)$ & 0.002 & 9.204 \\
\hline $2-3$ months & $0.27(0.12-0.58)$ & 0.001 & 10.816 \\
\hline $3-4$ months & $0.43(0.22-0.84)$ & 0.014 & 6.097 \\
\hline $4-5$ months & $1.31(0.77-2.22)$ & 0.323 & 0.979 \\
\hline $5-6$ months & $9.15(5.65-14.84)$ & 0.000 & 80.719 \\
\hline $6-9$ months & $27.28(17.21-43.23)$ & 0.000 & 198.107 \\
\hline Over 9 months & $24.78(15.00-40.95)$ & 0.000 & 156.915 \\
\hline Inconsistent & $10.80(5.80-20.10)$ & 0.000 & 56.312 \\
\hline
\end{tabular}

Continues.. 


\begin{tabular}{|c|c|c|c|}
\hline \multicolumn{4}{|c|}{...Continuation } \\
\hline Variables & OR (IC 95\%) & p & Wald's Chi-square \\
\hline \multicolumn{4}{|c|}{ Health Unit District } \\
\hline 00 & $0.001(0.000-0.011)$ & 0.000 & 40.283 \\
\hline I & $1.60(1.09-2.36)$ & 0.018 & 5.639 \\
\hline II & $1.26(0.89-1.79)$ & 0.185 & 1.756 \\
\hline III & $0.88(0.62-1.25)$ & 0.489 & 0.478 \\
\hline IV & $2.87(2.01-4.11)$ & 0.000 & 33.138 \\
\hline $\mathrm{V}$ & $1.23(0.89-1.71)$ & 0.206 & 1.602 \\
\hline VI & 1.00 & 0.000 & 106.583 \\
\hline
\end{tabular}

\section{DISCUSSION}

In the univariate analysis, the variable age was significantly associated with a favorable TB treatment result $(p<0.0001)$ and also with all its categories. Individuals in age categories with less than 60 years had a greater chance of cure than those aged over 60 . After changes made following the multivariate analysis, children and adolescents in the age ranges 0 to 9 and 10 to 19 had their chances of cure increased by respectively 4.27 and 1.78 times more than individuals aged over 60 .

Some authors explain that patients aged over 60 have a smaller chance of cure due to the following reasons: greater vulnerability to adverse effects of therapy; difficulty in accessing healthcare services for TB diagnosis and/or treatment; difficulty in recognizing the condition, which is frequently confused with changes typical of aging and other diseases such as smokers' chronic bronchitis and emphysema because of similar symptoms, such as coughing, weight loss, weakness, and dyspnea(5-7).

Among the factors responsible for higher TB morbidity and mortality in the elderly are: malnutrition, living in institutions for the elderly, associated diseases, alcoholism, smoking, and drug abuse ${ }^{(6)}$.

The variable education was associated with a favorable result $(p<0.0001)$ in the univariate analysis. Categories 1 to 3 years of education and does not apply showed no association with a favorable result. The final model showed an association between the category 8 to 11 years of education and a favorable TB treatment result. The chance of cure for those individuals was 1.52 times greater than that of patients with no education. Previous studies have reported low education in patients with an unfavorable treatment result ${ }^{(8-9)}$.

Of the 4,750 study cases, only $774(16.26 \%)$ had a record showing more than 8 years of education. The importance of providing patients with appropriate treatment instructions must be emphasized. This is especially true for those individuals with low education, with a lack of information, who show addictive interaction, and which constitute a category of increased default risk ${ }^{(9)}$. Some authors ${ }^{(10)}$ suggest educational waiting room group sessions, associating daily or twice-weekly supervised treatment with sponsorship and home visits done in higher risk groups.
For the variable type of entry, results found after the multivariate analysis showed that new cases and recurrence had chances of cure, respectively, 3.31 and 3.32 times greater than that of re-treatment after default. New cases have close to $100 \%$ chance of cure provided that treatment principles are followed ${ }^{(11)}$. As for re-treatment cases (retreatment after default, recurrence, or failure), in Brazil in 2001 only $47 \%$ obtained treatment success ${ }^{(4)}$.

A 1997 study carried out in the city of Recife, Pernambuco state, verified that default was the main reason for re-treatment (55.8\%), followed by recurrence (39.2\%). Patients who returned to treatment after recurrence had more favorable results (64\%) compared to those who returned after default or failure of the previous treatment ${ }^{(8)}$.

Some authors ${ }^{(9,12)}$ state that the lower chances of cure for patients who returned to treatment after default may be due to the fact that those patients have a default history for various reasons: the sensation of being cured; side effects to the medication; TB-associated diseases, such as AIDS and alcoholism; or yet, aspects regarding healthcare services, such as delay in service, difficulty in accessing healthcare professionals, inaction of contacting absentees, poor patient/healthcare professional relationship, and failures in treatment instruction. Patients who do not understand treatment implications have a stronger chance of neglecting them ${ }^{(13)}$.

Another predictor refers to the treatment period. TB patients who completed treatment in 5 to 6 months had a chance of cure 9.15 times greater than those who completed it in a shorter time. Concerning this specific period, it must be observed that there may have been errors in reporting the treatment's starting and ending dates. The chance of cure for individuals who completed treatment in 6 to 9 months was increased by 27.28 times and by 24.78 times for those who took more than 9 months. A longer TB treatment may occur due to irregularities regarding the patient, medication, and/or healthcare delivery.

However, it is worth mentioning that the longer the treatment, the greater the chance of default, along with its biological, economical, psychological, and social implications. Moreover, irregularities in following the treatment scheme increases risks for resistance, treatment failure, and consequently, worsening of the clinical condition, and even death ${ }^{(14)}$. 
In order to reach the goal of producing epidemiologic impact, case identification and treatment must have the greatest coverage possible and maximum treatment regularity ${ }^{(15)}$. Once treatment is initiated, it must not be interrupted, except if determined by rigorous clinical and laboratorial review ${ }^{(16)}$.

Treatment control consists of periodic disease evolution assessments and a correct use of medications. For this to occur, it is essential that healthcare professionals ensure the basic conditions for treatment success. The healthcare team must inform patients about the importance of his or her collaboration in treatment and establish a relationship of mutual cooperation. The team must provide guidance in terms of: the disease; treatment duration and importance of regularity; and inform of the serious consequences of treatment interruption or default ${ }^{(16)}$.

The final model also revealed that cases followed up by healthcare units belonging to Sanitary Districts (SD) I and IV had a chance of cure, respectively, 1.60 and 2.87 times greater than those followed up by units belonging to SD VI.

SD VI is one of the districts that concentrates a greater number of SZSI (Special Zones of Social Interest). In Recife there are 66 SZSI which represent $80 \%$ of 490 slums, including $40 \%$ of Recife's population. A lower chance of cure may be related to deprived areas with precarious conditions of life.

Elevated morbidity and mortality rates of long-known public health problems, such as TB, in certain urban areas reveal the need to understand the relations between urban environment/urban poverty and the existence of superposed sanitary conditions ${ }^{(17)}$. Not always do slum inhabitants, sex workers, and homeless people have access to healthcare services. When they do they are usually not fully assisted to their specific and most urgent needs. This shows that healthcare action programs need to be reformed and adapted $^{(18)}$.

\section{FINAL CONSIDERATIONS}

The statistical method used in this study, the multivariate logistic regression model, allowed for identifying predictors of favorable TB treatment results. By analyzing those factors, a priority group was identified. That group is composed of individuals aged over 60 , with no education, and who were submitted to re-treatment after default. The two factors identified as main obstacles to treatment success were: not completing treatment time and healthcare units belonging to SD in deprived areas.

It is suggested that more attention be given to the elderly with special focus on diagnosis, treatment and care. This is due to: specific clinical characteristics that differentiate them from adults in general, their histories, and consequent TB-related events.
When low/no education, lack of information, and additional interactions which may cause lower chances of recovery are considered, it is suggested that investments should be made in training healthcare professionals so they can offer better guidance and information about TB. This is particularly true for the elderly. The importance of medical treatment is a scientific concept that is not always fully understood and accepted by people who do not share this paradigm. TB education should aim to provide knowledge and explanations about the disease and its treatment, and attempt to establish a bond that favors trust in scientific knowledge.

Individuals being re-treated, especially in cases of return after default, must also be considered as a risk group in TB Control Programs. This is because these individuals tend to abandon treatment and frequently remain ill, and thus more exposed to the transmission of drug-resistant bacilli. Efforts should be made in order to improve healthcare service efficacy towards this group, certifying medication intake through supervised treatment as well as offering education and embracement activities. It must be taken into consideration that everyone has the potential to change their behavior provided that they know and understand the reasons and benefits of such changes.

In regards to the obstacle to treatment success identified based on the variable Time 2 , it is necessary to clarify to the patient about treatment duration, since complying completely with treatment allows most patients to be cured. Considering that there are many ways and degrees of not following treatment (from eventually forgetting to take the medication to intentionally interrupting or abandoning treatment), it is important to recognize which conditions predispose patients and which interventions are indispensable. To assess compliance with treatment, one can observe the regularity of medication intake by counting pills in the package.

Further studies are needed in order to deeper analyze the relationship between TB treatment results and deprived areas with precarious conditions of life. Such studies should associate TB spatial distribution with the populations socioeconomic and sanitary conditions.

Therefore, it is suggested that a specific organization be developed in healthcare services to individually assist TB patients by giving priority to groups with lower chances of cure. This would ensure not only access to healthcare services but also equity in actions. This shift in focus, it is believed, would be an improvement in care given to priority groups with positive effects on epidemiologic indicators of the disease in Recife.

There was, however, one limitation to the present study. That was the record in categories such as ignored, inconsistent, does not know, forwarded, waiting for result, and not tested of variables that did not represent data which allowed analysis. 


\section{REFERENCES}

1. World Health Organization (WHO). Global tuberculosis control: surveillance, planning, financing. Geneva; 2006.

2. Brasil. Ministério da Saúde. Secretaria de Vigilância em Saúde. Sistema Nacional de Vigilância em Saúde. Relatório de situação. Brasília; 2005.

3. Pernambuco. Secretaria Estadual de Saúde. Diretoria Geral de Atenção à Saúde. Diretoria Executiva de Atenção Básica. Coordenação de Tuberculose. Ações de controle da Tuberculose: relatório anual (2004). Recife; 2005.

4. World Health Organization (WHO). Global tuberculosis control: surveillance, planning, financing. Geneva; 2004.

5. Dube D, Feather J, Katz PR, Reichman W. Clinical features of pulmonary tuberculosis in young and old veterans. J Am Geriatr Soc. 1987;35(6):512-5.

6. Vendramini SHF, Villa TCS, Cardozo-Gonzales RI, Monroe AA. Tuberculose no idoso: análise do conceito. Rev Lat Am Enferm. 2003;11(1):96-103.

7. Lituak J. El envejecimiento de la poblacion: un desafio que va más allá del ãno 2000. Bol Sanit Panam. 1990;109(1):1-5

8. Campos HMA, Albuquerque MFM, Campelo ARL, Souza WV, Brito AM. O retratamento da tuberculose no município do Recife, 1997: uma abordagem epidemiológica. J Pneumol. 2000;26(5):235-40.

9. Ribeiro SN. Abandono do tratamento da tuberculose: aspectos do tratamento mal conduzido: discussão dos possíveis fatores como causa do abandono do tratamento específico da tuberculose e a situação bacteriológica após o abandono [dissertação]. Rio de Janeiro: Universidade do Estado do Rio de Janeiro; 1993.
10. Ribeiro AS, Amado VM, Camelier AA, Fernandes MMA, Schenkman S. Estudo caso-controle de indicadores de abandono em doentes com tuberculose. J Pneumol. 2000;26 (6):291-6.

11. Brasil. Ministério da Saúde. Fundação Nacional de Saúde. Centro de Referência Professor Hélio Fraga. Sociedade Brasileira de Pneumologia e Tisiologia. Controle da Tuberculose: uma proposta de integração ensino-serviço. Rio de Janeiro; 2002.

12. Oliveira HB, Marin-León L, Gardinali J. Análise do Programa de Controle da Tuberculose em relação ao tratamento em Campinas-SP. J Bras Pneumol. 2005;3(2): 133-8.

13. Santos Filho ET. Tempos de mudanças para o controle da tuberculose no Brasil. Rio de Janeiro: Public Health Watch/Open Society Institute; 2006.

14. Sassaki CM, Arcêncio RA, Costa Júnior ML, Palha PF, CardozoGonzales RI, Villa TCS. Tempo de tratamento de pacientes inscritos no Programa de Controle da Tuberculose: Ribeirão Preto-SP (1998-1999). Bol Pneumol Sanit. 2002;10(2):27-34.

15. Azuma Y. A simple simulation model of tuberculosis epidemiology for use without large-scale computers. Bull World Health Organ. 1975;52(3):313-22.

16. Brasil. Ministério da Saúde. Secretaria de Políticas Públicas. Departamento de Atenção Básica. Coordenação Nacional de Pneumologia Sanitária. Plano de Controle da Tuberculose no Brasil no período de 2001-2005. Brasília; 2000.

17. Souza WV, Ximenes R, Albuquerque MFM, Lapa TM, Portugal $\mathrm{JL}$, Lima MLC, et al. The use of socioeconomic factors in mapping tuberculosis risk areas in a city of northeastern Brazil. Rev Panam Salud Publica. 2000;8(6):403-10.

18. Marsiglia RMG, Silveira C, Carneiro Júnior N. Políticas sociais: desigualdade, universalidade e localização na saúde no Brasil. Saúde Soc. 2005;14(2):69-76.

\section{ACKNOWLEDGMENT}

This study received support from Coordination for the Improvement of Higher Education Personnel (CAPES); The State of São Paulo Research Foundation (FAPESP) Thematic Project, process n. 03/08386-3, and The Brazilian TB Research Network (REDE-TB). 